Received: 05.07.2014; Final Text: 29.03.2016

Keywords: Socio-economic segregation; residential segregation; status groups; transformation; Ankara.

1. Portions of this article are based on the author's doctoral thesis submitted to Middle East Technical University (2014) titled

"Reading Turkish Urbanisation through Socio-Economic Residential Segregation in 15 Cities".

\section{A DIVIDED CAPITAL: RESIDENTIAL SEGREGATION IN \\ ANKARA (1)}

Ela ATAÇ*

\section{INTRODUCTION: ANKARA IN THE PERIOD OF TRANSFORMATION}

The 2000s have certainly been a period of massive changes in Turkish society. Looking backwards, one can safely argue that nothing has remained the same in Turkey since the early 2000s, which marks probably one of the most significant turning points in near history in political, social and economic terms. In this decade, Justice and Development Party (JDP) won three successive elections starting in 2002, increasing its share of votes in each case. The success of the JDP, an Islamist-leaning party, represented a turning point in Turkish political history and was surely unimaginable as far as the political climate of the 1990s is considered. In the economic sphere, Turkey registered a remarkable growth over the ten years, to such an extent that it is expected to be one of the world's fastest growing economy between the years of 2012 and 2017 (OECD, 2012). The gross domestic product (GDP) per capita, for instance, improved in this period, jumping from 3,492\$ in 2002 to $10,067 \$$ in 2010 according to Turkish Statistical Institute (TurkStat) figures. Yet in this term, not only the macro economy, but also the social and institutional infrastructure have been subjected to structural transformations with neoliberal policies being implemented in all aspects. First and foremost, regulatory state interventions in social and economic sphere have reached such levels that were unthinkable in previous periods. The relations with the European Union during this period also provided an important context for the implementation of a neoliberal agenda with explicit social and regulatory components (Öniş, 2012). The health and social security systems were adjusted in line with these new reforms. Public expenditures, for instance, especially in the realms of health and education have considerably grown. In terms of percentages, health spending that accounted for $3.7 \%$ of GDP in 2002 increased to $4.4 \%$ in 2011. 
All these changes may seem trivial when compared to the changes that took place in Turkish cities in the first decade of the 2000s. In this period, Turkish cities underwent a radical and comprehensive restructuring at a pace and scope that would render insignificant all the transformations of the previous periods. What is striking in this new era is the fact that this was a transformation initiated and managed to a large extent by the state as opposed to the previous changes, where the state played a passive role in urban regulation. First and foremost, the development of the construction sector reached a speed never seen before in the country's urbanization history. According to the TurkStat data, while the annual growth rate of the construction sector was only $4.9 \%$ in the year of 2000 , it grew by $18.3 \%$ in 2010. The boom in the construction of housing projects of the Housing Development Administration (HDA) of Turkey widespread in almost every city of the country and the mushrooming of large-scale investments in the urban areas such as colossal infrastructure investments in transportation, giant shopping malls, luxury residences in or around business centers are a few of the examples that would give an idea on the dimensions of the transformation that irrevocably changed the face of Turkish cities. It must be stressed in this context that a great share of the housing projects of the 2000s aimed at the eradication of the housing stock of previous periods. To give an example, HDA housing projects implemented in the existing housing stock is approximately $20 \%$ of all housing projects held by HDA (HAD, 2010). Transformation and renewal projects took place mainly in the older and historical central areas and former squatter settlements of many greater cities and by implementing the recent law on the transformation of areas under the risk of natural disaster, $40 \%$ of the existing housing stock (approximately 7 million buildings) will also be subject to reconstruction (Ministry of Environmental and Urban Planning, 2013). These numbers may help one come to terms with the scale and size of the massive transformations that Turkish cities have undergone in recent years, at a rate never seen before in Turkish urbanization history.

Ankara, as the capital of Turkey, is one of the major cities of the country where this transformation process can be best observed. According to the Population and Housing Survey carried out by the TurkStat in 2011, for instance, the proportion of housing stock built in the last twenty and ten years in Ankara is $63.6 \%$ and $37.0 \%$ respectively. Since the 1990s, there has been a boom in the construction of ultra-luxurious gated communities by large developers to meet the growing demand from high income groups in the major cities of the country (Işık and Pınarcıoğlu, 2009). The new elites change their location in the city and move from centers to peripheries to live in more isolated residences and thereby the relationship of the new upper and lower classes both with the rest of society and the city has severely changed in this period. However, despite the dynamism of this new era, it can be claimed that our knowledge about the extent of this transformation process is still relatively poor. We do not know well, for instance, how the existing social and physical urban fabrics, public life or urban life have affected and been affected by these transformations. We also have limited knowledge, for instance, about the winners and the losers of this new process.

On these grounds, the essential concern of this article is simply to reach the clues about this transformation process lived in the country through the socio-economic and residential segregation dynamics of its capital city, Ankara, by taking a snap-shot of Ankara in the year 2000. In an attempt to read and understand the social structure of Ankara at the dawn of the 
2. As far as segregation is concerned in Turkish urban studies, the ones which focus on the urban patterns and processes are very limited. Some of those exceptions are made by Güvenç (2001), Güvenç and Işık (2002), Işık and Pınarcıoğlu (2009), Akpınar (2008). transformation era in the 2000s "segregation" is defined as the port of entry (2). This article is, thereby, an attempt to understand the roots of this transformation period through residential segregation in Ankara. The data used in the study and selection of variables to define socio-economic status and segregation are explained in the following section. The quantitative aspects of the study on methodological processes used to present the patterns of segregation in socio-economic line are described in detail in the section after that. Following the methodology the results are further discussed with reference to segregation maps of Ankara for 2000. Finally a section is devoted to understanding the groups that reveal the segregation patterns and the paper ends with an extended discussion on not only the direct findings of the study but the transformation process that Turkish cities have currently experienced.

\section{THE DATA AND VARIABLES}

The data used in this study is the 2000 census (at neighborhood level) provided by Turkish Statistical Institute (TurkStat). 2000 Census is conducted in traditional method which makes it the last extensive microlevel data set in Turkey in which the demographic, social and economic characteristics of population are available at neighborhood level. As far as the metropolitan area of Ankara is defined as case area, the data is reorganized in a way to include only the neighborhoods that are within the 2000 metropolitan boundaries of the cities. Since income data is not available in this data set, socio-economic status is defined with multiple variables. In an attempt to generate socio-economic segregation in Ankara the neighborhoods are classified on the basis of three sets of variables namely education, demography and employment which have strong capacity to reveal socio-economic segregation in Turkey. To give an example, a study on poverty in Turkey (Işık and Ataç, 2011) shows that the rate of poverty among university graduates in urban areas in 2008 is $0.9 \%$ as opposed to $15.1 \%$ in primary school graduates, and 36.8 $\%$ among illiterates in Turkey indicating the fact that education can be defined both as a cause and effect of social inequality in Turkey. The poverty rates among women population is, on the other hand, highly related with education levels. According to TurkStat data for 2006 the rate of poverty among women university graduates in urban areas is $0.5 \%$ as opposed to $12 \%$ in primary school graduates, and $32.8 \%$ among illiterate women. In other terms the less educated a woman, the more likely she is in poverty. Poverty risk of individuals can also change depending on their employment status. While the rate of poverty among the regular wage earners is $5.9 \%$, this rate is $27.4 \%$ among causal wage earners, 1.8 $\%$ among employers, $21.3 \%$ among the self-employed and $29.6 \%$ among unpaid family workers (Işık and Ataç, 2011). In Ankara, therefore, it is the combination of these multiple variables which reveals socio-economic differences and these variables are presented below. These multiple variables are put into clustering analyses in order to reach different socioeconomic status groups in Ankara in a way explained in the next section in detail.

\section{A. Education}

A1. Adult literacy

A2. The difference of female and male literacy

A3. University graduates 


\section{B. Employment status}

B1. The difference between male and female labour force participation

B2. Manufacturing sector employees

B3. Finance, insurance, real estate and business service employees

B4. Top level white collar workers

B5. Scientific, technical, professional and related workers

B6. Employers

C. Demography

C1. Child-woman ratio

C2. Native population

C3. Population who has the household size of 3

\section{THE METHODOLOGY: MAPPING SEGREGATION \& DERIVING THE GROUPS}

The analysis of segregation in Ankara proceeds in two main stages: identifying segregation patterns and group profiles which, in combination, pave the ground to explain and understand the residential divisions of the city. These two phases individually offer the opportunity to explore the nature of segregation in Ankara and it is the integration of these narratives which has the potential to provide a more comprehensive understanding of residential segregation specific to the city. To classify residential areas in Ankara using multiple variables defined before, clustering analyses (k-means and fuzzy clustering algorithms) are used. Segregation maps revealed by clustering algorithms are provided in Figures 2, 3 and 4 with two additional maps given in Figures 5 and $\mathbf{6}$ whilst the group profiles are listed in Tables 1 and 2.

The first step here is to understand residential segregation pattern of Ankara through its segregation maps calculated via k-means clustering. Clustering is mostly done using the k-means clustering algorithm, a simple non-parametric clustering method, where " $\mathrm{k}$ " stands for the number of clusters (Brimicombe, 2007). It aims to group the members of a unit into number of groups in which each member of the unit belongs to the group with the nearest mean as a prototype of the group. The objective of the k-means algorithm is, therefore, to minimize the within-cluster variability (De Ville, 2006). This clustering algorithm is employed for the whole population of Ankara in the study. To illustrate, Figure 1 shows the bivariate clustering plots of some variables of Ankara which show that in the clustering process, whereas being a white collar worker has a linear and directly proportional relation with university graduation, it is inversely
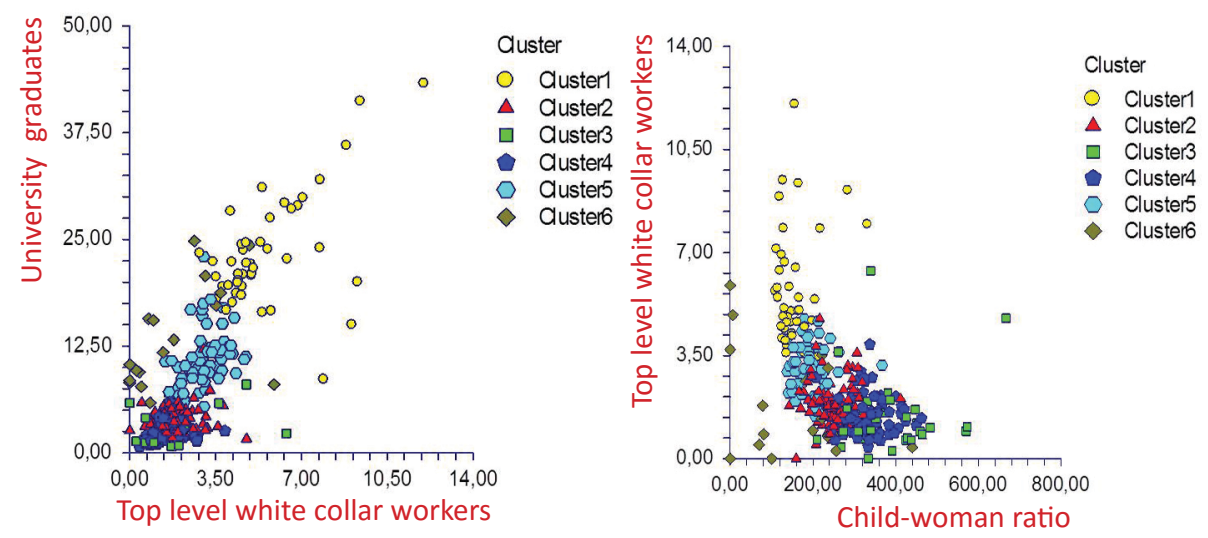
proportional with the fertility rates and the clusters are, thereby, defined according to those relations between multiple variables. When this method is employed to all neighborhoods of Ankara by the variables defined before, segregation maps are produced. Segregation map of Ankara produced by k-means clustering, thereby, shows residential distribution of six socio-economic status groups (high, middle and low status groups with two subgroups in each) within the city. Segregation pattern of the city (clustering, congregating etc.) can be clearly seen in this map where neighborhood groups are denoted with letters from A to $\mathrm{F}$ where A represents the highest status neighborhoods and " $\mathrm{F}$ " the lowest ones (see Figures 2 and 3 ).

In addition to segregation map, a complementary map named fuzzy map produced by fuzzy clustering algorithm is also provided for Ankara. The basic rationale behind fuzzy clustering is that an object may belong to more than one cluster. In the binary logic or common clustering, the set is limited by the binary yes/no definition, meaning that each object corresponds to one cluster only. But in fuzzy clustering, objects can be associated with multiple clusters to different degrees (Grekousis and Thomas, 2012; Grekousis et al. 2013). Each cluster has a cluster center that represents a typical object in the cluster and a membership value (between 0 and 1) that reveals how close each object is to the center of a cluster. This value, in a sense, can be termed as a probability of belonging in one cluster. In the study, with fuzzy clustering, each neighborhood within a city is assigned a factor of being in the highest status group (Group A). Following the application of fuzzy clustering algorithm, the neighborhoods are classified according to their membership values. The optimal number of clusters is five in the analysis. The results of the membership values can be mapped as well and this map basically shows the probability of being in Group A of each neighborhood in the urban area. Fuzzy map of Ankara produced by this way, thereby, shows the probability on the part of a randomly selected person from each neighborhood of belonging to the highest status group of the city (see Figure 4). In fuzzy clustering map, lighter colors represent the least and the darker colors represent the most likely places to be exposed to a member of the highest status group (Group A) in Ankara.

After analyzing segregation maps of the city, in an attempt to get a deeper understanding of status groups, group profiles of Ankara are documented. Focusing on the groups is to expand the depth of understanding on the structure of segregation by recognizing the status groups in detail. In other words, this phase is the answer to the questions of who are those status groups defined in the urban area. In order to answer this question the characteristics of the groups in basic segregation map are documented in profile tables of Ankara (see Tables 1 and 2).

\section{PATTERNS OF SEGREGATION: TWO SIDES OF COIN - THE WEALTHY SOUTH AND THE POOR NORTH}

Segregation map of Ankara, which shows the residential distribution of socio-economic status groups in neighborhood-level is provided in Figure 2, whereas the basic divisions seen in this map are visualized in Figure 3. The maps show in the first place that all status groups are highly unevenly distributed across the city, in the form of a north-east and south-west division. First in terms of segregation, it is the non-contiguity of two poles of the status groups which is probably the most interesting and crucial finding. It is interesting to see that segregation maps of Ankara reveal 
Figure 2. Segregation map of Ankara

Figure 3. Main divisions in segregation map of Ankara
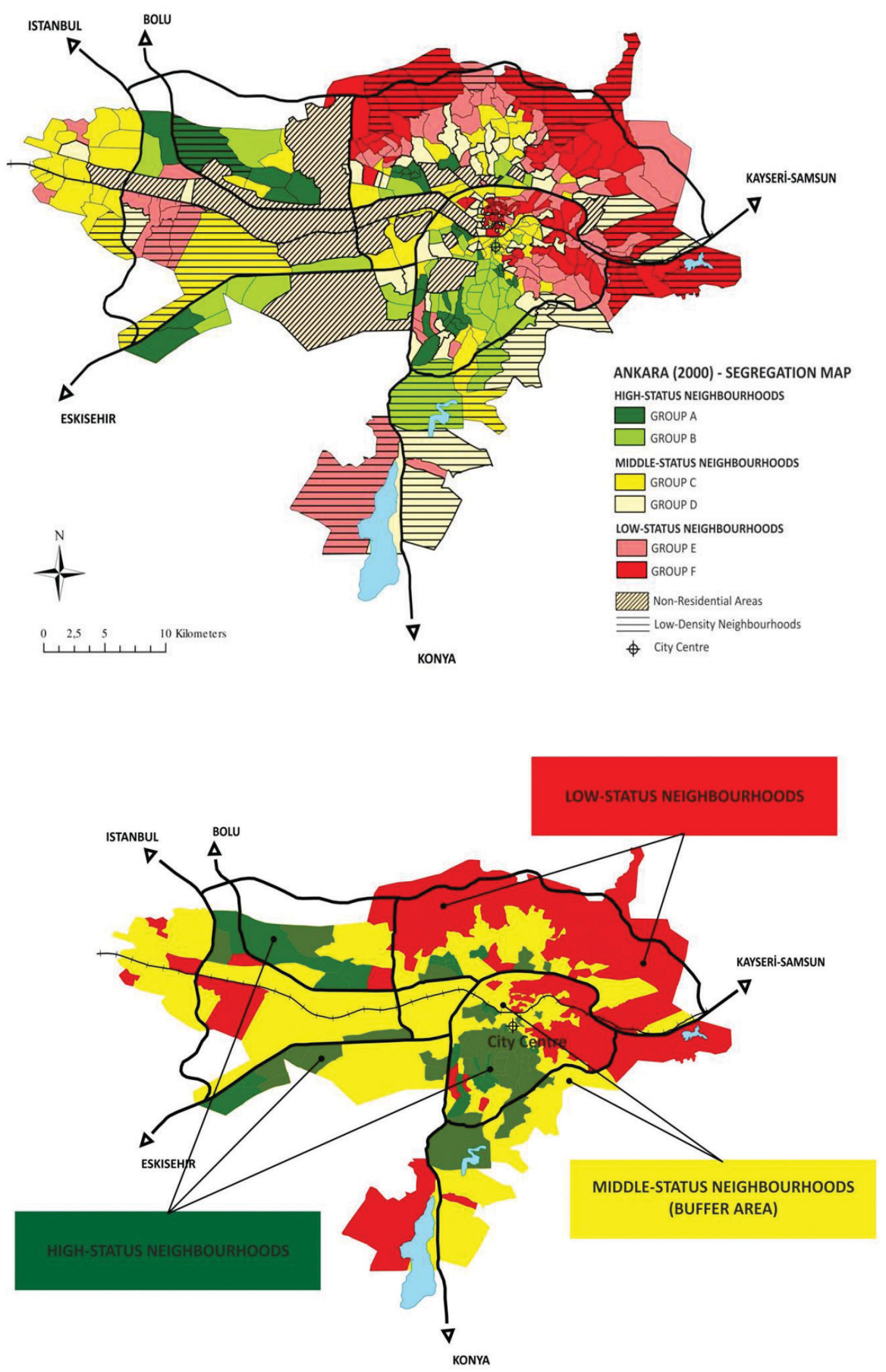

a pattern where the highest and the lowest status groups never share a common border in the urban area and the middle status groups act as a buffer between these groups (Figure 3). This almost flawless picture does not even let the wealthy and the poor meet each other in the urban setting and it can evidently be said that this pattern based on the denial of common borders between the winners and the losers of the city. This picture can also be defined for Ankara as the characteristic segregation pattern. 


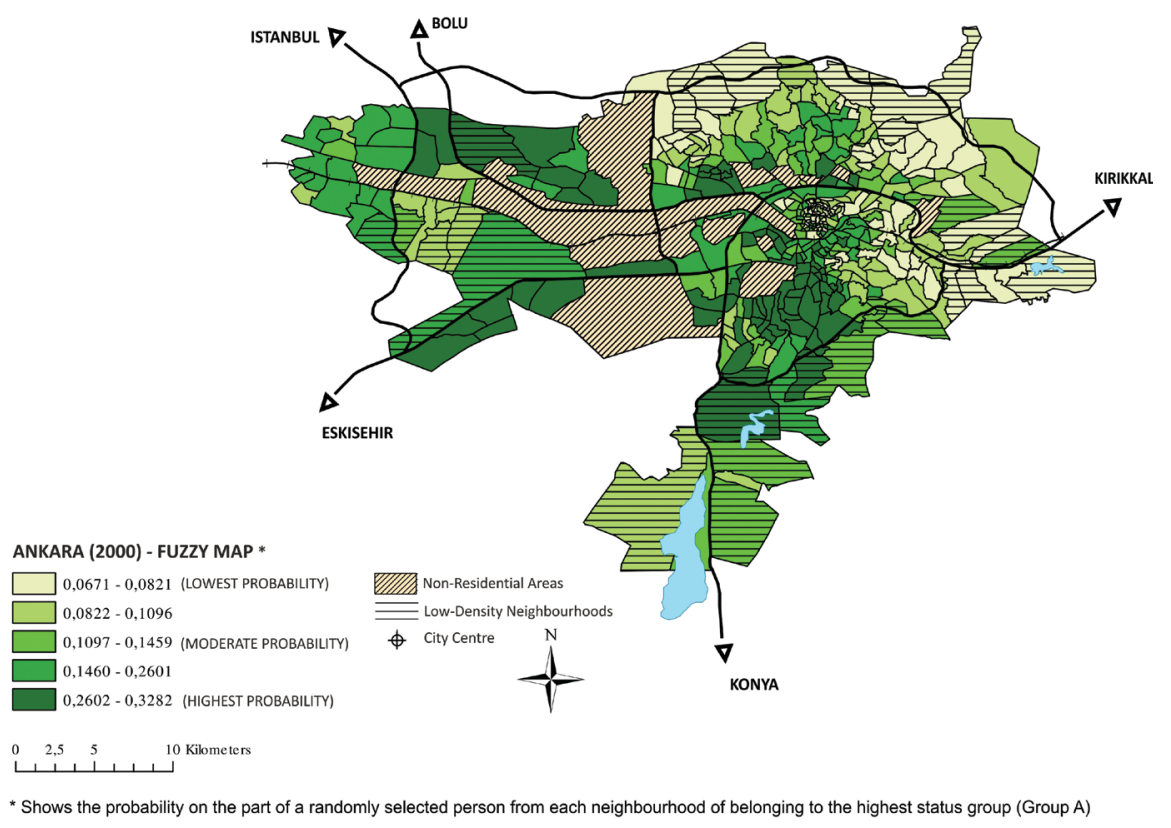

As a matter of fact, these main divisions of the city comes from a traditional division of the north (where poorer groups live) and the south (where the upper classes occupy) of until the 1980s. The railway once was the border between these two areas with inverse characters as well (Akçura, 1971). However as of the 1980s, with the expansion of the better-off residential areas in the western axis of the city and squatter developments in eastern areas, this dual picture has somewhat changed into the north-eastern and south-western division. In this new residential pattern, it is the IstanbulSamsun highway which serves as a border between the wealthier and poorer areas. Fuzzy map of Ankara which shows the probability on the part of a randomly selected person from each neighborhood of belonging to the highest status groups (see Figure 4) verifies this division as well. As can be clearly seen from this map, the probability of seeing a member of the highest status group of Ankara gets higher in the southern and western parts of the city where the opposite holds true for the eastern and northern areas. In other words, Ankara is characterized by a clear split between the highest status groups living in north and north-eastern areas and the lowest status groups in south and south western parts of the city.

According to the segregation maps of Ankara in Figures 2 and 3, high segregation is clearly visible between the highest and the lowest status groups. For instance, as far as these two poles are concerned, spatial divisions are distinct and rigid. Moreover, wealthier and poorer groups are likely to be segregated and isolated both from the rest of the city and from each other in the urban area. It should also be noted that it is the wealthier groups which dominate the segregation pattern. As can be seen from each segregation map of Ankara (see Figures 2, 3 and 4), better-off groups are more dispersed in the urban area whereas lower groups are highly clustered in a certain place of the city indicating that the groups which have the ability to mobilize and expand in the urban area are upper status groups. The locational choice of the upper groups has two main characteristics; being closer to the newly developed areas or being closer to the central areas (CBD). This is a point that needs to be further emphasized. 
First and foremost, it can be claimed that Ankara follows almost the same path of the urbanization process proposed for Turkey. The history of urbanization till the 2000s is, for the most part, the history of squatter housing in Ankara. Yet, it has been widely known that the 1980s and 1990s have also been a period in which social and residential distance between the low and high income groups has been further expanded in the metropolises and the debates about globalization and its effects on class formations and urban patterns have been discussed. In the late 1990s, housing options of upper and middle income groups were also diversified. Decentralization process has been already started in the larger metropolises including Ankara both by the urban poor located in the peripheries and by the coalition of middle and upper income groups, developers and state actors as well (Geniş, 2007). When the segregation pattern of Ankara in 1990 produced by Güvenç (2001) is compared with the segregation maps provided in the figures, it is clearly seen how the divisions between the status groups have changed even in a decade. The neighborhoods defined as the peripheries or the transition areas in the maps of 1990 seem to turning into a more clarified zone of low status in the 2000s whereas the high status groups (white collars) of the 1990 are getting larger in 2000 map preserving their spatial power in the west and south axis of the city. This means that the binary spatial structures of the earlier terms gave way to a more divided and fragmented urban fabric where the wealthier and the poorer neighborhoods tended to be more segregated than ever before. As Kurtuluş (2011) claims, the speed of the construction of the gated communities in the late 1990s can compete with that of the first generation squatter settlements in this term. This is exactly what is experienced in Ankara. Angora Evleri and Beysukent located largely in the south western axis of the city are some of those earlier gated communities. This suburbanization movement can be best seen in segregation maps of Ankara (Figures 2, 3 and 4).

Looking at these patterns it can easily be claimed that the southern and south eastern corridors of Ankara which can be defined as Istanbul axis, Eskişehir/Oran zone and central southern zone according to the zoning definitions of Şenyapılı (2001), are the most attractive parts of Ankara for the new urban development. This means that this trend is not likely to change in the near future. On the contrary, the isolation and segregation of upper status groups would be expected to grow faster in the late 2000s with the new spatial formations mushrooming along these routes of the city where urban services such as sport, shopping, entertainment and even education facilities and private security become more accessible today than it was in the year of 2000 .

In this highly divided city picture covered mainly by the upper and lower classes, middle class seems to be dispersed across the city with the lack of a decisive pattern in urban place. With some exceptions, they mainly and only serve as the barriers between the two poles of status groups which tend to keep away from each other to the possible extent. Note that here one can clearly see the impact of urban transformation projects on segregation patterns as well. The rare conditions where the highest and the lowest status groups touch each other are seen especially in areas close to city center which can partly a result of earlier urban transformation projects. Figure 5 shows the urban renewal projects of Ankara overlapped with the segregation pattern of the city. Dikmen Valley, Portakal Çiçeği, Geçak urban development projects carried out in the southern areas of the city and also seen in the figure can serve as the best examples to illustrate 
Figure 5. Urban regeneration zones in Ankara

3. It should be noted here that among those projects it is the Dikmen Valley and Geçak projects where it is aimed to keep their own residents and therefore they have long been referred as successful implementations in urban transformation projects.

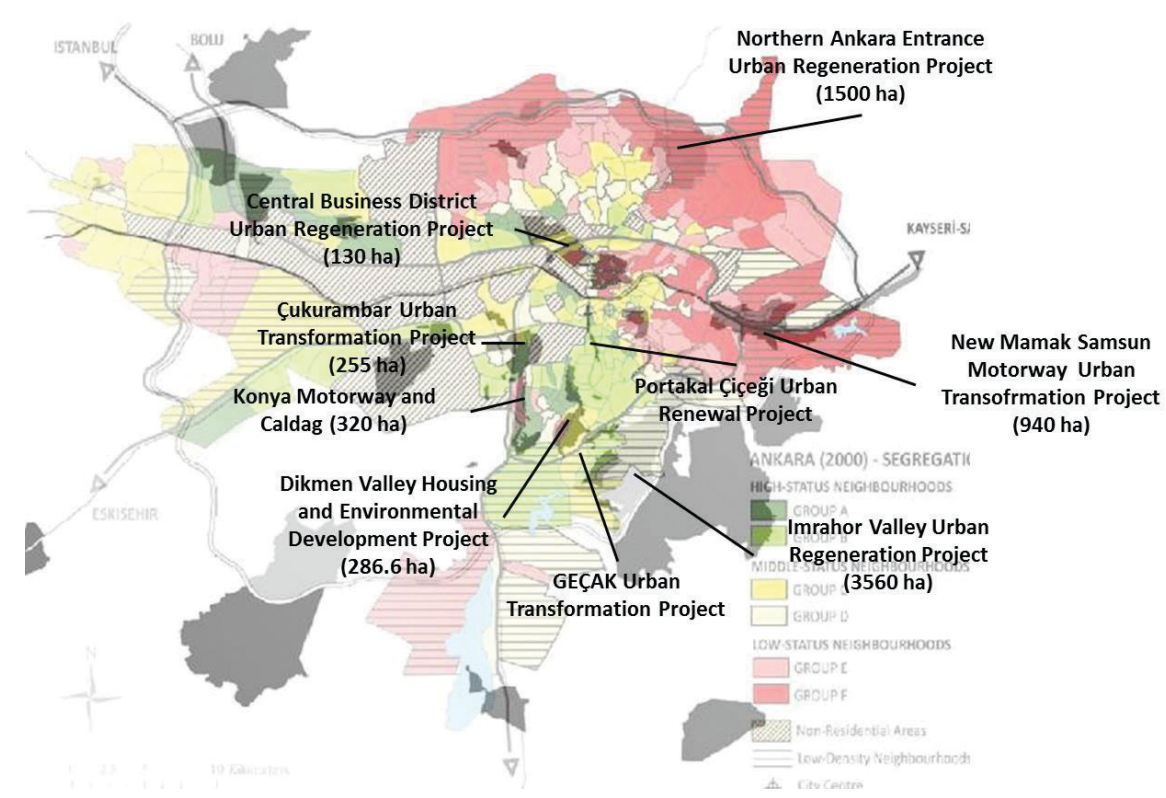

this. Smaller clusters of low status neighborhoods located among high status areas in the southern part of the city in segregation map, therefore, explain why these areas have been subject to urban transformation projects (3). These early urban development projects aimed to clear this larger area from squatter settlements which once largely occupied this southern part of the city. It can be said, thereby, that these projects had trigger effect in transforming this part of the city to a high status residential area.

In Ankara, the growing suburbanization trend of the new upper classes has also had its clear impact on the segregation pattern. To this end, segregation maps of Ankara shed further light on the residential choices of upper and upper-middle classes. It can evidently be said that while new high status groups occupy the neighborhoods in the south-western corridor (Eskişehir-Oran zone: Çayyolu, Ümitköy and Istanbul axis such as Batıkent) of the city, the upper-middle and middle status neighborhoods, in a sense the neighborhoods where the traditional middle classes of Ankara reside, are located mainly in the axis that runs from the city center to the southern parts (Central south: Cebeci, Ayrancı, Çankaya Gaziosmanpaşa, Öveçler) of the city. These groups can be refferred to as traditional and newer upper and middle classes. According to Keyder (2013), the main difference between the traditional and newer middle classes is that while traditional classes once had the social norms that would be accepted by the whole society, such as being high educated, working in public sector and being residentially closer to central urban services, the norms of newer classes are now based on horizontal relations which make them able to share their cultural consumption routines with their own-types only, such as living in sheltered neighborhoods, working in prestigious companies, meeting their own types mainly in suburban communities and the like. Yet, in Turkish metropolises in general and in Ankara in particular the traditional upper and middle classes can also be defined with the different age profiles. To illustrate, Figure 6 shows the share of people older than 60 years old by neighborhoods in Ankara. Even a quick glance at this map helps to see that the neighborhoods which have the highest shares of older people are located in the central areas of the city (the areas defined as middle and upper status groups in segregation maps - Figures 2 and 3) 
Figure 6. Share of people older than 60 years old by neighborhoods in Ankara
4. Istanbul and Ankara are, undoubtedly, the major cities where Turkey's class-based change of location and the turn-over of the center in this change is most obviously witnessed. Among the various studies on this transformation, Tekeli (1994) and Tümertekin (1997) stand out as defining the center just as it has been defined here, through processes of change of location and re-structuring.

5. The works of Erder (1996), Işı1k and Pınarcıoğlu (2001), Perouse (2011), Şenyapılı (1982) and Ayata (2008) are some of the good examples in this greater literature.

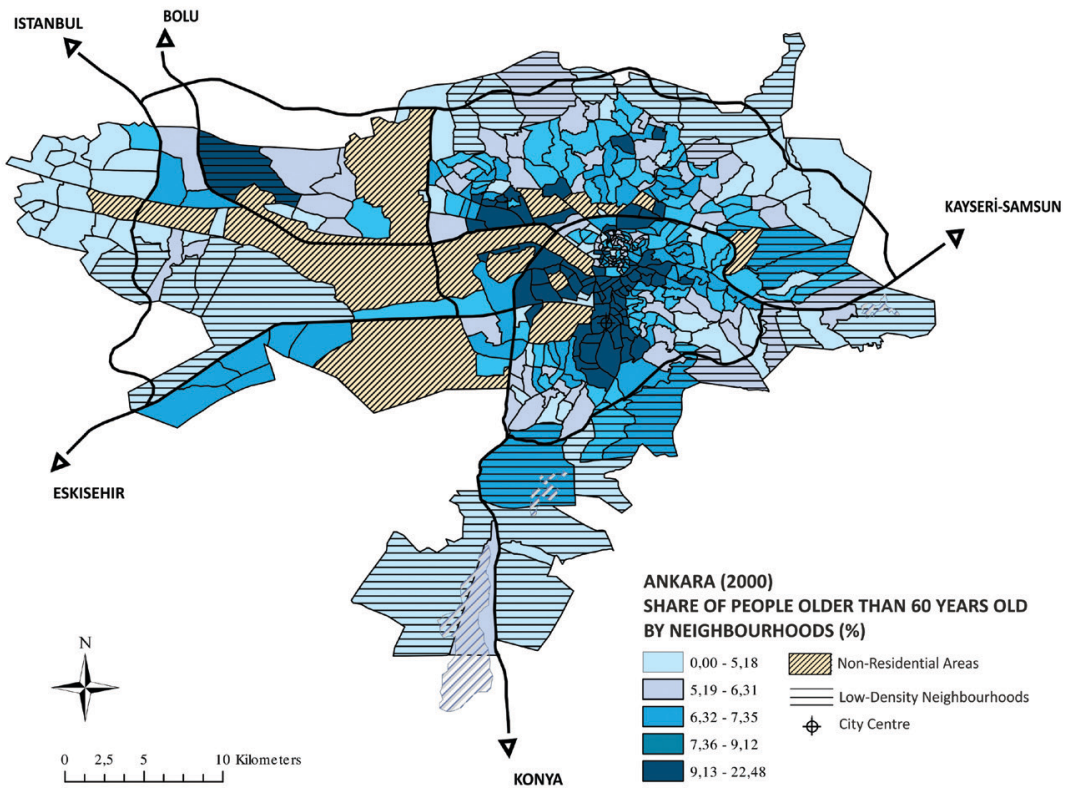

and this share gets gradually lower from center to the peripheries as well. This means that even in the metropolises of Turkey which enable flights of upper classes from center to peripheries, there are still traditional older groups living in the central areas of cities.

This simply indicates that as far as the urban rich are concerned in Ankara there are two different groups which can be defined as the traditional (an older population stuck in the city center) or the newer upper or upper-middle classes (a more mobile and younger group located in the peripheries or closer to the new development areas) according to their location within the city. This is a feature of Ankara that is exclusively on its own. It is known, for instance, that in the United States the dense migration of the upper income groups in the center, known as white flights, to outside of the city started in this way. This suburbanization process has also been frequently discussed for the major Turkish cities including Ankara through the problematic of the center becoming rundown (4). However, in Ankara, the process of change of location among the groups may not correspond to Western-style forms. As has been repeatedly underlined here, in Ankara, not the city center itself but the areas around the central core still holds its power in urban formations at the beginning of the years of 2000, and it does not seem probable that it will completely lose its value in the days to come. On this basis, one can also conclude that unlike Western cities where decentralization has been experienced with a complete dislocation of the wealthier classes from center to the periphery, in Ankara, there are still some trapped wealthier groups located around the center which seem to be getting older and have, probably, less mobility than the other wealthier groups.

Another key finding of the pattern analysis is about the lowest status groups who reveal "dispersed clusters" in the urban area (Figures 2 and 3). These areas are, without doubt, the survival places of the urban poor who benefit from residentially gathering in order to strengthen their solidarity networks and on which there is also a voluminous literature in Turkish urban studies (5). It would not be wrong to claim that low status 
groups that present such a strong clustering in urban place cannot be defined as the passive partner of an urban system by any means. But the only dynamic that would affect these areas in the near future would be new attempts on urban regeneration and transformation of the deprived areas which became one of the main income sources of the municipalities. Urban regeneration projects which gained momentum and even changed form after the year 2000, HDA applications and new urban development probably render the recent urban patterns different from the picture defined. Urban patterns, however, deciphered in the maps given in the Figure 5 where urban renewal projects of Ankara are overlapped with the segregation pattern of the city is also of a nature that would enable the reading of the spatial traces of the transformation period initiated, in a way, by the period after 2000. What is interesting to see in this map is that this transformation process is experienced more rapidly especially by the low status neighborhoods located close to the highest status groups defined in the 2000 segregation maps. Note that former squatter housing areas built in the fringe of the city in the 1950s are now located in the central areas of Ankara. As can be seen from Figure 5 more clearly where the comparison of segregation map and some recent urban renewal projects are exemplified in Ankara, the renewal projects of the 2000s in urban area are almost without exception held on those neighborhoods located closer to the upper class neighborhoods. In other words, it is mainly the intersection areas of the red and green neighborhoods in the central areas that are mainly subject to those renewal and transformation projects. In the peripheries, however, it is mostly the empty lots where HDA projects are carried out.

This means in a simpler sense that the recent urban transformation projects held in Ankara seek primarily not an urban renewal but a clearance process in the urban area. This makes clear that the urban poor who are historically known as the active partner of the urban systems with their self-made networking relations in the cities would be the most affected segment of the society from this transformation process in this new term.

\section{WHO ARE THE GROUPS? DEMOGRAPHIC PROFILES OF THE STATUS GROUPS}

In order to get a better understanding of the group characteristics, group profiles shown in basic segregation map of Ankara are derived and provided in Table 1 whereas in Table 2, the prominent characteristics of the status groups coming both from pattern and groups analyses are summarized.

In the profile table given in Table 1, the columns represent the variables and the rows show the status groups from Group A to F for Ankara. The status groups given in the rows also need to be explained in some detail. In the profile table, the rows of Group A to F represent the percentage of relevant variable within a status group in the city; namely, looking at the first variable (UNI) in the table, the percentage of university graduates in Group A in Ankara. To give an example from the table, $23 \%$ of those living in Group A neighborhoods in Ankara are university graduates, as opposed to $3.4 \%$ in Group F neighborhoods. City row represents the percentage of relevant variable within the city. In this example, it is the percentage of university graduates within the total Ankara population. The share of university graduates in Ankara is $12.9 \%$ as opposed to $23 \%$ in those classified as Group A in Ankara. TR (urban) row represents the percentage of relevant variable within the total population of urban areas in Turkey. 


\begin{tabular}{|c|c|c|c|c|c|c|c|c|c|c|c|c|}
\hline & UNI & CWR & NATIVE & $\mathrm{HH}$ & WRK_F & WRK_P & PROF & TW & MANUF & FIRE & EMP & DIST \\
\hline GROUP A & 23.0 & 157.1 & 45.8 & 58.0 & 24.5 & 40.8 & 27.9 & 6.7 & 10.1 & 15.4 & 9.8 & 9.5 \\
\hline GROUP B & 21.0 & 154.1 & 40.1 & 59.5 & 29.0 & 39.9 & 33.4 & 8.7 & 7.5 & 16.8 & 7.8 & 14.8 \\
\hline GROUP C & 12.5 & 215.2 & 46.2 & 45.2 & 18.5 & 38.6 & 19.7 & 4.2 & 13.0 & 10.6 & 4.3 & 22.9 \\
\hline GROUP D & 11.3 & 259.5 & 48.0 & 43.7 & 16.9 & 38.4 & 18.2 & 4.7 & 13.5 & 10.8 & 4.9 & 16.0 \\
\hline GROUP E & 3.7 & 347.6 & 48.6 & 33.7 & 9.6 & 35.3 & 9.1 & 2.2 & 19.4 & 6.9 & 2.8 & 27.2 \\
\hline GROUP F & 3.4 & 360.8 & 49.5 & 33.5 & 8.9 & 33.7 & 9.0 & 2.3 & 22.0 & 7.1 & 2.8 & 19.4 \\
\hline CITY & 12.9 & 274.5 & 46.4 & 44.9 & 17.5 & 38.6 & 20.0 & 4.9 & 13.8 & 11.3 & 4.8 & 100 \\
\hline TR(urban) & 9.0 & 327.9 & 55.4 & 41.0 & 12.0 & 32.0 & 9.0 & 5.5 & 20.0 & 4.7 & 4.2 & -- \\
\hline
\end{tabular}

Table 1. Group Profiles of Ankara (\%) (6)

6. The abbreviations used for the variables in the table are as follows; UNI: university graduates; CWR: child-woman ratio; NATIVE: the native population; $\mathrm{HH}$ : the persons who live in the households with three people and below; WORK_F: female working population; WORK_P: total working population; PROF: scientific, technical, professional and related employees; TW: top level white collar workers; MANUF: manufacturing sector employees; FIRE: finance, insurance, real estate, and business service employees; EMP: the employers. DIST, the last column in the table, represents the percentage of population living in the relevant status group.
The most notable feature about the group profiles of Ankara is that group shares of upper and middle status groups are far better than Turkey averages as well as the urban averages for almost all variables. As indicated in the table, especially for variables such as university graduation, child-woman ratio, and native population, Ankara represents favorable percentages -i.e. higher shares in university graduation, lower fertility rates, and lower shares of native population- especially for high status groups. For instance, looking at the group profile values one can say that in Ankara higher education plays a significant role in upper-class positioning. In absolute terms, the percentage of university graduation of the city is 12.9 $\%$ opposed to $9 \%$ the urban areas in Turkey considered as a whole. This figure rises up to 23 and 21 percents for the people living in high status neighborhoods (Group A and Group B respectively) which simply means that almost one out of every five people holds a university degree in upper classes and it is around $10 \%$ for middle classes as well. It is only low status groups where higher education rates are considerably lower. This means that better education is positively correlated with higher status in Ankara. This may be because of the fact that Ankara is the capital city where public sector takes the lion's share in employment and, thereby, the service sector is the key sector in its economic development, which requires more qualified and well-educated people.

Variables related with female population are also significantly higher especially in upper and middle status groups of Ankara. Put more concretely, child-woman ratio which is a proxy for recent fertility is found 274.5 for the entire city whereas it is 327.9 for all urban areas in Turkey. Except low status groups of the city, fertility rates are considerably lower than Turkey averages. This figure is documented for higher groups around 150 and 200-250 for middle classes. However, when female participation in labor force is considered, it is seen that higher status groups represent a greater share with a group percentage value of 25 and 30 which means that almost three out of every ten women living in the highest status neighborhoods of Ankara are in employment. Note that this rate is considerably higher when both the city and the country averages are considered. The higher trend of participation in labor force among female population is also seen among middle classes. Both of two levels of middle status groups (Group C and Group D), group shares of working women is higher than city and country averages; 18.5 and $16.9 \%$ of female population involved in Group C and Group D respectively participate in labor force whereas this figure is 17.5 and 12 for city and total urban areas in Turkey. When it is considered that female rates of participation in labor force are remarkably and exceptionally lower in Turkey, these rates may be explained with reference to the dominant role of the public sector which is more open to the female workforce in Ankara and as well as the higher education levels pervasive within the city. However, this positive 
picture slightly changes when low status groups are considered. The share of working women is considerably low in Group E and Group F with the percentages around 8 and 9 only which shows that women in the lower segments of society have still problems with integrating the labor market in Ankara.

When employment status of groups is considered it is not surprising to see that high status groups have higher shares of high-prestigious occupations such as white collars and finance sector employees whereas middle class contains a great share of professionals. In proportional terms, white collars accounts for $6.7 \%$ in the highest status group whereas the overall highest status group share in total population of Ankara is $4.9 \%$ and 5.5 for entire Turkey. Finance sector employees in the higher status groups have also greater shares in Ankara with the percentage values of 15.4 and 16.8 whilst the urban and Turkey averages account for 11.3 and $4.7 \%$ respectively. Note that the group shares of these two occupational groups are both greatly higher than both city and Turkey averages.

Although group percentage of professionals in the highest status group, Group A, is relatively higher (27.9\%), it is mainly the second-level high status groups (Group B) and middle status groups which have significantly higher shares of professionals even from that of the highest status group. In Group B, $33.4 \%$ of employers are professionals. For the middle and lower classes, however, the shares of the professionals within the groups are considerably lower as far as the urban and Turkey averages are considered which are 20 and $9 \%$ respectively. These results, therefore, prove that it is mainly the upper-middle class professionals that are concentrated in the capital city where there are many public sector organizations and employees.

In terms of native population, all status groups reflect almost the same shares around 40-45 percents, indicating that being native does not seem to play a significant role in Ankara citizens' class positions. This can be interpreted for Ankara in a dual way. First, as one of the larger metropolises of Turkey, Ankara has a cosmopolite population and this trivializes the roots of people which is traditionally effective to be member of upper classes especially in Anatolian cities (7) This may be again related with the dominance of public sector which does not allow networking relations can be observed in other sectors. Second, in a city where the majority of immigrants are from nearby cities and even from its farther districts, place-of-birth may naturally not be an effective factor to be involved in upper status groups.

All these statistics consequently show that Ankara has its own socioeconomic rules in its class formations. This can be summarized as high education, lower rates at child-woman ratio, being involved in the highly prestigious occupation groups or working in public sector and the low difference between the genders in the rates of participation in labor force. In simplistic terms, the more one has positive rates in these variables the more likely he/she is to be falling into the higher status groups in Ankara.

In Table 2, these main findings of group analysis are combined with the main findings of the pattern analyses. Accordingly, people with the qualifications such as university graduates, white collar workers, professionals such as engineers, professors etc. can only be able to live in the wealthier southern and south western parts of the city as well. The renewal projects of the 2000s in urban area held mainly on the 


\begin{tabular}{|c|c|c|c|}
\hline & High Status & Middle Status & Low Status \\
\hline 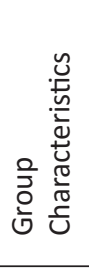 & $\begin{array}{l}\text { - High education } \\
\text { - Lower rates at child-woman ratio } \\
\text { - Being involved in the highly } \\
\text { prestigious occupation groups or } \\
\text { working in public sector } \\
\text { - Low difference between the } \\
\text { genders }\end{array}$ & $\begin{array}{l}\text { - Level of education is relatively low } \\
\text { compared to high status groups } \\
\text { - Composed of a more } \\
\text { heterogeneous population in } \\
\text { which professionals, employers, } \\
\text { finance sector employees can take } \\
\text { place together }\end{array}$ & $\begin{array}{l}\text { - Low education } \\
\text { - Passive role of female population both in } \\
\text { the household and in urban life } \\
\text { - Having difficulty in integrating to the } \\
\text { labor market }\end{array}$ \\
\hline 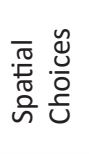 & $\begin{array}{l}\text { - They live in the southern and } \\
\text { south western parts of the } \\
\text { city (closer to CBD or other } \\
\text { developed urban facilities) }\end{array}$ & $\begin{array}{l}\text { - They constitute a larger buffer } \\
\text { area between high and low } \\
\text { groups }\end{array}$ & $\begin{array}{l}\text { - They occupy the north eastern region } \\
\text { of the city where the urban services, } \\
\text { resources and opportunities are limited }\end{array}$ \\
\hline 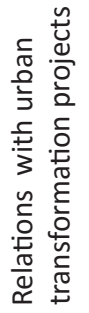 & $\begin{array}{l}\text { - The renewal projects of the } \\
\text { 2000s in urban area held mainly } \\
\text { on the neighborhoods closer to } \\
\text { the upper status neighborhoods }\end{array}$ & $\begin{array}{l}\text { Middle status areas closer to the } \\
\text { central urban area are the ones } \\
\text { which seem to be affected most by } \\
\text { the urban transformation projects }\end{array}$ & $\begin{array}{l}\text { - Low status neighborhoods in the central } \\
\text { areas are mainly subject to renewal and } \\
\text { transformation projects } \\
\text { - In the peripheries, it is mostly the empty } \\
\text { lots where HDA projects are carried out } \\
\text { and some of those projects are also held } \\
\text { closer to the lower status neighborhoods } \\
\text { in the peripheries }\end{array}$ \\
\hline
\end{tabular}

Table 2. Prominent Characteristics of the Status Groups in Ankara neighborhoods closer to the upper status neighborhoods. The middle class is, on the other hand, composed of a more heterogeneous population in which professionals, employers, finance sector employees can take place together. Their level of education, however, is relatively low compared to upper status groups. Although the middle-class neighborhoods located closer to western and southern axes of the city are also separated with clear borders from the lower status groups in urban area, they mostly serve as the negotiator between the two-ends of society constituting a larger buffer area between them. In terms of urban transformation projects, it can be said that middle status areas closer to the central urban area are the ones which seem to be affected the most by the urban transformation projects as well.

Those living in the deprived neighborhoods occupy the north eastern region of the city where the urban services, resources and opportunities are limited. It is mainly the low status neighborhoods in the central areas subject to renewal and transformation projects as well. There are, moreover, convincing evidences in the study which shows low education, passive role of female population both in the household and in urban life and having difficulty in integrating to the labor market are both the reason and the result of those massive deprived and excluded areas in the north eastern region of the city. One of the interesting findings of this study is, therefore, the effect of education and women-related variables that have capability of categorizing socio-economic groups. Education is one of the most important descriptive variables to define residential and social segregation in Turkey and so in Ankara although it alone would not be sufficient to define the socio-economic status groups. The more educated the more chance to be involved in the upper segments of society. Adding to these issues the variables associated with women further clarifies the picture at hand in dissecting different types of socio-economic structures in different cities. Those proxy variables are the strongest factors in upward mobility. 


\section{CONCLUDING REMARKS}

This article on segregation dynamics of Ankara shows how the nature of segregation in Ankara is unique due to its peculiar physical, economic and social structures. However, it also reveals that an effort to read a city, Ankara, through the year of 2000 would provide invaluable insights not only into the segregation dynamics of the city but also recent transformation process and the new forms of urban structures likely to emerge in this new term. This is because of the fact that invisible boundaries between people cannot be easily changed, shattered or crossed over and may continue to exist long after the visible boundaries have been erased. Spatial practices do not take place on a tabula rasa; on the contrary, new set of relations articulate with the long-established previous spatial practices in particular ways. New social or economic processes are built onto the existing geographical, historical and even cultural textures or the long-established relations/networks and, thereby, the pattern emerges in a long course of time. This is also exactly the case for segregation patterns in Ankara. When the residential divisions along socio-economic line are considered from this point of view, it can safely be claimed that most of what can be said for the year of 2000 are the roots of today's urban social and residential patterns. First in terms of segregation, it is the noncontiguity of two poles of the status groups which is probably the most interesting and crucial finding. It is interesting to see that segregation maps of Ankara reveal a pattern where the highest and the lowest status groups never share a common border in the urban area and the middle status groups act as a buffer between these groups. This almost flawless picture does not even let the wealthy and the poor meet each other in the urban setting and it can evidently be defined as the characteristic urban pattern of Ankara. Second, as far as the status groups are analyzed it is seen that the group characteristics are completely different which also means that there are some characteristic ways of climbing up to socio-economic ladders in Ankara. These socio-economic rules in class formations can be summarized as high education, lower rates at child-woman ratio, being involved in the highly prestigious occupation groups or working in public sector and the low difference between the genders in the rates of participation in labor force. In simplistic terms, the more one has positive rates in these variables the more likely he/she is to be falling into the higher status groups in Ankara.

It is important to underline here that this picture drawn upon Ankara's socio-economic geography of the year 2000 may be regarded as a snapshot of the city before the transformation era. Urban transformation projects which gained momentum and even changed form after the year 2000 probably render the recent urban patterns different from the picture defined in the article. This transformation process is, for instance, experienced more rapidly especially by the low status neighborhoods located close to the highest status groups defined in the 2000 segregation maps of the city. As it is shown in Figure 5 where the comparison of segregation map and the recent urban renewal projects is exemplified, the renewal projects of the 2000s are almost without exception held on those neighborhoods located closer to the upper class neighborhoods. In other words, it is mainly the intersection areas of the high and low status neighborhoods and the empty lots on the peripheries that are mainly subject to those renewal and transformation projects. Therefore, by looking at the urban segregation patterns provided in the article it can be inferred for Ankara that low status neighborhoods close to the new development 
areas are highly likely to be subject to new regeneration and urban transformation projects in the near future. This also means that new spatial and socio-economic divisions and even the group definitions in the city will be drawn by those transformation projects in this new term.

Urban planning, to this end, has profound effect on social and residential interaction of different groups living in the cities. Creating public spaces where people from different walks of life can meet and interact, providing affordable housing for every segment of the society, and proposing mixedincome settlements are some of the main tools of urban planning for creating an integrated society. To this end, although the scope of the article does not allow making such a discussion here, developing urban policies or guiding planning principles for integration of society both socially and residentially will contribute not only to the field but also to the urban development trends of Ankara.

\section{ABBREVIATIONS}

TurkStat: Turkish Statistical Institute

JDP: Justice and Development Party

GDP: Gross Domestic Product

HDA: Housing Development Administration of Turkey

CBD: Central Business District

\section{BIBLIOGRAPHY}

AKÇURA, T. (1971) Ankara: Türkiye Cumhuriyeti'nin Başkenti Hakkında Monografik Bir Araştırma, ODTÜ Mimarlık Fakültesi, Ankara.

AKPINAR, F. (2008) Class Dimension of Housing Inequalities in The New Era of Liberalization: A case study in Ankara, METU Journal of Faculty of Architecture 25(2) 39-69.

ATAÇ, E. (2014) Reading Turkish Urbanization through Socio-Economic Residential Segregation in 15 Cities, Unpublished Ph.D Dissertation, Middle East Technical University, Ankara.

ATAÇ, E. (2013) Büyük Dönüşüm Öncesi Türkiye Kentlerini Okumak, Anlamak: Sosyo-Ekonomik Statüye Bağlı Mekansal Ayrışma Üzerinden Bir Değerlendirme, Toplum ve Bilim 126 35-64.

AYATA, S. (2008) Migrants and Changing Urban Periphery: Social Relations, Cultural Diversity and the Public Space in Istanbul's New Neighbourhoods, International Migration 46(3) 27-65.

BANK, A., KARADAG, R. (2012) The Political Economy of Regional Power: Turkey Under the Akp (204: September), GIGA Research Unit: Institute of Middle East Studies, Hamburg, Germany.

BRIMICOMBE, A. J. (2007) A Dual Approach to Cluster Discovery in Point Event Data Sets. Computers, Environment and Urban Systems 31 4-18.

DE VILLE, B. (2006) Decision Trees for Business Intelligence and Data Mining: Using SAS Enterprise Miner, SAS Press Series, NC.USA.

ERDER, S. (1996) İstanbul'a Bir Kent Kondu: Ümraniye, İletişim Yayınları, İstanbul.

GENIŞ, Ş. (2007) Producing Elite Localities: The Rise of Gated Communities in İstanbul, Urban Studies 44(4) 771-98. 
GREKOUSIS , G., MANETOS, P., PHOTIS, Y. N. (2013) Modelling Urban Evolution Using Neural Networks, Fuzzy Logic and GIS: The Case of the Athens Metropolitan Area, Cities 30 193-203.

GREKOUSIS, G., THOMAS, H. (2012) Comparison of Two Fuzzy Algorithms in Geodemographic Segmentation Analysis: The Fuzzy C-Means and Gustafson-Kessel Methods, Applied Geography 34 12536.

GÜVENÇ, M. (2001) Ankara'da Statü/Köken Farklılaşması; 1990 Sayım Örneklemleri Üzerinde "Blokmodel" Çözümlemeleri, Tarih İçinde Ankara II, Der. Y. Yavuz, ODTÜ Mimarlık Fakültesi Yayınları, Ankara.

GÜVENÇ, M., IŞIK, O. (2002) A Metropolis at The Crossroads: The Changing Social Geography of Istanbul Under the Impact of Globalization, Of States and Cities: The Partitioning of Urban Space (203-220), Eds. P. Marcuse, R. Van Kempen, Oxford University Press, Oxford.

HDA-Housing Development Administration (2010) Geleceğin Türkiye'sini Inşa Ediyoruz [http://www.toki.gov.tr/AppResources/UserFiles/files/ TOKI-11_TRK.pdf] Access Date (12.03.2015).

IŞIK, O., PINARCIOĞLU, M. (2001) Nöbetleşe Yoksulluk, İletişim Yayınları, İstanbul.

IŞIK, O., PINARCIOĞLU, M. M. (2009) Segregation in Istanbul: Patterns and Processes. Tijdschrift voor Economische en Sociale Geografie 100(4) 469-84.

IŞIK, O., ATAÇ, E. (2011) Yoksulluğa Dair: Bildiklerimiz, Az Bildiklerimiz, Bilmediklerimiz. Birikim, (268-269).

KEYDER, Ç. (2013) Gezi Olaylarının Seyrini Türkiye'de Yükselmekte Olan Yeni Orta Sınıf Değiştirmiştir. [http://t24.com.tr/haber/keyder-geziolaylarinin-seyrini turkiyede-yukselmekte-olan-yeni-orta-sinifdegistirmistir/238849] Access Date (19.10.2013).

KURTULUŞ, H. (2011) Gated communities as a representation of new upper and middle classes in İstanbul, İ.Ü. Siyasal Bilgiler Fakültesi Dergisi 44 49-65.

Ministry of Environmental and Urban Planning (2013) Kentsel Dönüşüm Sürecine İlişkin Sıkça Sorulan Sorular. [http://www.csb.gov.tr/ gm/altyapi/index.php?Sayfa=sayfahtml\&Id=2091] Access Date (04.02.2015).

OECD (2012) Economic Outlook, Report no: 91, Press Conference, Paris.

ÖNIŞ, Z. (2012) The Triumph of Conservative Globalism: The Political Economy of the Akp Era. Turkish Studies 13(2) 135-52.

PEROUSE, J. F. (2011) İstanbul'la Yüzleşme Denemeleri: Çeperler, Hareketlilik ve Kentsel Bellek, İletişim Yayınları, İstanbul.

POPE, H. (2010) Pax Ottomana? The Mixed Success of Turkey's New Foreign Policy, Foreing Affairs 89(6) 161-72.

POPULATION STUDIES CENTRE (2012) Racial Residential Segregation Census 2000 Findings. [http://enceladus.isr.umich.edu/race/racestart. asp] Access Date (27.12.2012). 
SARGIN, G.A. (2012) Ankara Kent Atlası, Mimarlar Odası Yayını, Ankara.

ŞENYAPILI, T. (1982) Economic Change and the Gecekondu Family, Sex Roles, Family and Community in Turkey, Indiana University Turkish Studies, Bloomington.

TEKELİ, İ. (1994) Development of İstanbul Metropolitan Area: Urban Administration and Planning, IULA-EMME Yayınları, İstanbul.

TÜMERTEKIN, E. (1997) İstanbul, İnsan ve mekan, Tarih Vakfı Yurt Yayınları, İstanbul.

\section{A DIVIDED CAPITAL: RESIDENTIAL SEGREGATION IN ANKARA}

Turkey has undergone large-scale structural changes in social, political, and economic spheres in the 2000s. In the changing political climate of the 2000s, not only social and political geographies, but also residential patterns of the cities have been subject to abrupt changes. The development of the construction sector reached a speed never seen before in the country's urbanization history. Growing numbers of transformation and renewal projects took place mainly in the older and historical central areas and former squatter settlements (gecekondu) of many greater cities. But, despite the dynamism of this new era, our knowledge about the extent of this transformation process is still relatively poor. Our knowledge on the bases, the scale and possible impacts of this transformation is still limited and partial. On these grounds, this article attempts to understand the roots of this transformation process in the year of 2000 through socio-economic residential segregation in the capital city of Turkey, Ankara. It is claimed that as one of the most debated issues in Turkish public agenda, examining segregation in analytical ways can provide useful insights and valuable clues as to understanding the socio-economic structure of the cities. The findings of the study show that Ankara is a highly divided city in socioeconomic lines and the urban dynamics of the recent years are related with the characteristic divisions of the city. The study, in this sense, not only provides an extended look into the segregation dynamics of the city, but also sheds light on the roots of this active and dynamic period of the 2000s, and thereby reveals the last picture of the city before the period of transformation.

Alındı: 05.07.2014; Son Metin: 29.03.2016

Anahtar Sözcükler: Sosyo-ekonomik ayrışma, kentsel ayrışma, statü grupları, dönüşüm, Ankara.

\section{BÖLÜNMÜŞ BİR BAŞKENT: ANKARA'DA KENTSEL AYRIŞMA}

Türkiye 2000'li yıllarda sosyal, politik ve ekonomik açıdan büyük ölçekli yapısal değişimlere sahne olmaktadır. 2000'lerin değişen politik ikliminde, kentlerin sadece sosyal ve politik coğrafyaları değil, yerleşim desenleri de önemli değişiklikler göstermektedir. Örneğin inşaat sektörü gelişimi ülke kentleşme tarihinde bugüne kadar görülmeyen bir hıza ulaşmış, özellikle büyük kentlerde, genellikle kentlerin eskiyen ya da tarihi merkezi alanları ile gecekondu bölgelerini konu alan kentsel dönüşüm ve yenileme projelerinin sayısı giderek artmıştır. Fakat yeni dönemin bu dinamikliğine rağmen, ülkede yaşanan dönüşüm sürecinin boyutlarına dair bilgimizin oldukça yetersiz olduğunu söylemek gerekir. Örneğin bu sürecin temelleri, ölçeği, olası etkileri ya da bu süreci hazırlayan etmenlerin 
neler olduğu konusunda oldukça kısmi ve sınırlı bilgimiz olduğu söylenebilir. Buradan hareketle bu yazı, ülkenin yaşadı ğ ${ }_{1}$ bu dönüşüm sürecinin temellerini başkent Ankara'nın 2000 yılı sosyo-ekonomik kentsel ayrışması üzerinden anlamayı amaçlamaktadır. Yazıda da belirtildiği gibi, Türkiye kamusal alanında en fazla tartışılan meselelerden biri olan ayrışma meselesini analitik yollarla analiz etmek, kentlerin sosyo-ekonomik yapılarını anlamada önemli ipuçları vermektedir. Bu çalışmanın sonuçları göstermektedir ki Ankara sosyo-ekonomik açıdan bölünmüş bir kenttir ve son dönemin kent dinamiklerinin kentin karakteristik ayrımları ile büyük ölçüde ilişkili olduğu görülmektedir. Bu anlamda bu çalışma, sadece kentin ayrışma dinamiklerine detaylı bir bakış geliştirmekle kalmamakta aynı zamanda bu dinamik dönüşüm sürecinin köklerine de 1şık tutmakta ve böylelikle dönüşüm dönemi öncesi kente dair son bir resim sunmaktadır.

ELA ATAÇ; B.CRP, M.CP, Ph.D

Received her bachelor's (2005) and master's degrees (2008) from Gazi University. Earned her Ph.D degree (2014) from City and Regional Planning Department at METU. Currently works as an assistant professor at TED University Department of City and Regional Planning. Main research areas include urban geography, urban sociology, residential segregation and poverty. ela.atac@tedu.edu.tr 